\title{
O tak zwanym szpiegu i terroryście koronnym
}

\author{
StanisŁaw Hoc \\ Katedra Prawa Karnego \\ Uniwersytet Opolski
}

1. Rozpoznawanie, przeciwdziałanie i zwalczanie szczególnie groźnych przestępstw, jak szpiegostwa, i przestępstw o charakterze terrorystycznym wymaga nadania właściwym służbom odpowiednich narzędzi prawnych, które były już znane i z powodzeniem stosowane w okresie II RP. Zdaniem R.A. Stefańskiego bezprawność czynu jest wyłączona, jeśli zachowanie sprawcy, wyczerpujące znamiona czynu zabronionego, jest wynikiem realizacji jego praw lub obowiązków. Chodzi o zachowania mieszczące się w granicach jego praw lub obowiązków określonych w ustawie. Głównie dotyczy to przedstawicieli organów państwowych, którzy wykonując nałożone na nich obowiązki służbowe, dopuszczają się czynu zabronionego. Jeżeli chodzi o ustawy, które przyznają określone uprawnienia do podejmowania czynności naruszających normy karne, można wymienić przede wszystkim ustawę o Policji, ustawę o Agencji Bezpieczeństwa Wewnętrznego oraz Agencji Wywiadu, ustawę o Służbie Kontrwywiadu Wojskowego oraz Służbie Wywiadu Wojskowego.

Zdaniem Z. Wiernikowskiego ${ }^{2}$ na treść uprawnienia lub obowiązku składają się trzy elementy: kompetencja, tryb realizacji kompetencji oraz przesłanka. Kompetencją nazywa autor przypisane danemu podmiotowi - generalnie i abstrakcyjnie ujęte — prawo do zachowania wyczerpującego znamiona czynu zabronionego. Przesłanka to element konkretyzujący kompetencję — prawnie określony warunek (zespół warunków) podjęcia i prowadzenia legalnego działania przez podmiot uprawniony. Tryb realizacji to reguły określające szczegółowo procedurę działania podmiotu uprawnionego. Podobny katalog proponuje W. Wolter ${ }^{3}$, lecz jedynie w odniesieniu do uprawnień i obowiązków służbowych.

1 R.A. Stefański, Prawo karne materialne. Część ogólna, Warszawa 2008, s. 148-149.

2 Z. Wiernikowski, Działanie w granicach uprawnienia lub obowiazku prawnego jako okoliczność wyłaczajaca bezprawność czynu, PiP 1987, z. 3, s. 82.

3 W. Wolter, Nauka o przestęstwie: analiza prawnicza na podstawie przepisów części ogólnej kodeksu karnego z 1969 r., Warszawa 1973, s. 198. 
Termin „kontratyp” to okoliczność wyłączająca bezprawność czynu sprawcy, realizującego ustawowe znamiona czynu zabronionego. Został on wprowadzony przez W. Woltera ${ }^{4} \mathrm{i}$ jest powszechnie akceptowany.

Należy przyjąć, że działania podejmowane przez funkcjonariuszy publicznych, mieszczące się w granicach uprawnień lub obowiązków przyznanych im przez przepisy prawa, (ustawy) stanowią kontratyp wyłączający bezprawność zachowań polegających na realizowaniu znamion typów rodzajowych przestępstw.

2. Polska w okresie II RP pozostawała w intensywnym zainteresowaniu obcych służb specjalnych (przede wszystkim niemieckich, sowieckich, litewskich), stąd konieczność opracowania przepisów prawnych określających przestępstwo szpiegostwa. Rozporządzenie Prezydenta RP z dnia 16 lutego 1928 r. o karach za szpiegostwo i niektóre inne przestępstwa przeciwko Państwu ${ }^{5}$ uchyliło moc prawną przepisów ustaw karnych państw zaborczych (dzielnicowych) w zakresie szpiegostwa.

Rozporządzenie z mocą ustawy z dnia 11 lipca 1932 r. - Kodeks karny ${ }^{6}$ w rozdziale XVII wprowadza pojęcie zbrodni stanu, a w rozdziale XVIII — przestępstwa przeciwko interesom zewnętrznym państwa i stosunkom międzynarodowym. Przepisy zawarte w tych rozdziałach nie obejmowały wszelkich możliwych stanów faktycznych przestępnej działalności skierowanej przeciwko państwu, np. szpiegostwa. Należy podkreślić, że przepisy rozporządzenia z 1928 r. przystosowane były do ustawodawstwa dzielnicowego, nie odpowiadało ono założeniom kodeksu karnego z 1932 r., musiało więc być zmienione po jego wejściu w życie. Lukę tę wypełniło nowe rozporządzenie Prezydenta RP z dnia 24 października 1934 r. o niektórych przestępstwach przeciwko bezpieczeństwu Państwa ${ }^{7}$, którego przepisy uzupełniały rozdziały XVII i XVIII kodeksu karnego z 1932 r., dotyczące przestępstw przeciwko państwu. W związku z zaostrzającą się sytuacją międzynarodową i zagrożeniami ze strony Niemiec hitlerowskich wydano dwa akty prawne, które uzupełniały dotychczasowe przepisy dotyczące przestępstw przeciwko państwu: 1) dekret Prezydenta RP z 22 listopada 1938 r. o ochronie niektórych interesów Państwa ${ }^{8}$, 2) ustawa z 23 czerwca 1939 r. o szczególnej odpowiedzialności karnej w przypadkach zbiegostwa do nieprzyjaciela lub poza granice Państwa 9 .

W II RP Oddział II Sztabu Głównego WP był służbą właściwą w zakresie ochrony kontrwywiadowczej i przeciwdziałania dywersji politycznej i wojskowej, współpracował ze Strażą Graniczną, Korpusem Ochrony Pogranicza, Policją Pań-

4 W. Wolter, Prawo karne. Zarys wykładu systematycznego. Część ogólna, Warszawa 1947, s. 130; idem, W sprawie społecznego niebezpieczeństwa i bezprawności, NP 1956, nr 2, s. 74.

5 Dz.U. Nr 18, poz. 160; S. Hoc, O szpiegostwie w ustawodawstwie karnym II Rzeczypospolitej, „Opolskie Studia Administracyjno-Prawne” 2012, X/1, s. 35-47.

${ }^{6}$ Dz.U. Nr 60, poz. 571.

7 Dz.U. Nr 94, poz. 851.

8 Dz.U. Nr 91, poz. 623.

9 Dz.U. Nr 57, poz. 367. 
stwową. Działalnością kontrwywiadowczą zajmował się Wydział IIb - Kontrwywiad i ekspozytury terenowe ${ }^{10}$.

Artykuł 2 rozporządzenia z 1934 r. stanowił:

Działanie nie jest bezprawne wtedy tylko, gdy podjęto je za zezwoleniem udzielonym:

a) przez Ministra Spraw Wojskowych lub upoważnione przez niego organa państwowe

— w związku z wykonywaniem zadań ochrony bezpieczeństwa Państwa Polskiego,

b) przez właściwą władzę naczelną lub upoważnione przez nią organa podległe w związku z wykonywaniem innych zadań państwowych.

Przepisy cytowanego rozporządzenia Prezydenta Rzeczypospolitej (art. 2) dawały podstawę prawną do działań kontrwywiadu w zakresie przewerbowywania agentów obcych wywiadów, jeżeli było to uzasadnione ochroną bezpieczeństwa Państwa Polskiego ${ }^{11}$.

Zdaniem J. Lareckiego ${ }^{12}$ przewerbowanie (odwrócenie, przenicowanie), stanowi nakłonienie pracownika kadrowego lub współpracownika obcej służby specjalnej do realizacji czynności operacyjnych (czynności operacyjno-rozpoznawcze) na korzyść prowadzącego przewerbowanie. Podstawy do przewerbowania mogą być różne; wynikają z konkretnych uwarunkowań i rozwoju sytuacji, np. obywatel został pozyskany do współpracy pod przymusem lub w wyniku szantażu i po powrocie do kraju poinformował o tym fakcie rodzime służby specjalne, które zdecydowały się na jego przewerbowanie w celu nawiązania gry operacyjnej z przeciwnikiem. Celem takiej gry byłoby rozpracowanie jego technik operacyjnych, w tym form i metod działania, kanałów łączności z agentem, a także ujawnienie innych agentów działających dla przeciwnika na terenie kraju. Inny częsty przypadek to dekonspiracja pracownika (agenta) na terenie przeciwnika i pod presją wynikających stąd konsekwencji (długoletnie więzienie) jego zgoda na przewerbowanie i realizację zadań na korzyść obcej służby specjalnej w tajemnicy przed własną centralą.

Według J. Makarewicza ${ }^{13}$

Art. 2 rozporządzenia zawiera realizację zasady ogólnej prawa karnego dotyczącej pozorów karygodności (nie ma przestępstwa tam, gdzie sprawca wykonuje swój zawód, spełnia swe obowiązki urzędowe), mimo pozorów karygodności nie ma przestępstwa, nie ma nawet bezprawia. Przepis art. 2 ma na oku kontrwywiad, przeciwdziałanie szpiegostwu przez pozorne pomocnictwo lub współdziałanie. Sprawa jest szczególnie aktualna przy art. $14 \S 3$

10 Por. np. A. Pepłoński, Kontrwywiad II Rzeczypospolitej, Warszawa 2002.

11 S. Hoc, Ksztaltowanie się odpowiedzialności karnej za przestępstwa przeciwko państwu, [w:] Państwo prawa i prawo karne. Ksiega Jubileuszowa Profesora Andrzeja Zolla, t. 2, red. P. Kardas, T. Sroka, W. Wróbel, Warszawa 2012, s. 1133-1148.

12 J. Larecki [w:] Polskie stużby specjalne. Stownik, red. K.A. Wojtaszczyk, Warszawa 2011, s. 169.

13 J. Makarewicz, Kodeks karny z komentarzem, red. nauk. A. Grześkowiak, K. Wiak, Lublin 2012, s. 328-329. 
i art. $16 \S 3$ rozporządzenia. Możliwe jest, że agent kontrwywiadu dla celów zebrania materiału dowodowego w sprawie winy agentów wywiadu obcego rządu - nie tylko weźmie udział w czynnościach przygotowawczych (art. 14) lub w porozumieniu (art. 16), ale nawet będzie inicjatorem jednego lub drugiego (agent provocateur). W zasadzie nie mógłby ów agent korzystać z bezkarności mimo doniesienia na czas o przestępstwie. Inaczej sprawa się przedstawia z chwilą, gdy stwierdzimy, że działanie było prawne (czy też nie było bezprawne) od początku. Nie ma mowy o przestępstwie w ogóle, zasada czynnego żalu nie wchodzi w grę a także nie ma zastosowania wyjątek od bezkarności. Przepis art. 2 należy stosować ściśle, „zezwolenie” musi być wyraźne, a nie dorozumiane.

\section{Zdaniem L. Peipera ${ }^{14}$}

Art. 2 rozporządzenia zawiera dorozumiane stwierdzenie ogólnej zasady prawa karnego materialnego, że tylko bezprawie rodzi odpowiedzialność w myśl art. 1 k.k. Zarazem jednak — ze względu na doniosłość dóbr przepisami nin. rozp. chronionych — piętnuje on jako bezprawie (art. a contrario ze słów nie bezprawne) wszelkie przez kogo bądź (osobę prywatną, urzędnika państwowego lub innego, a nawet urzędnika naczelnych władz) Państwa (bez różnicy jego stanowiska) popełnione działanie, a także zaniechanie, przewidziane w art. $21 \mathrm{nin}$. rozp., jeśli nastąpiły bez przypisanego, a więc wyraźnego i specjalnego zezwolenia osoby do tego uprawnionej. Sprawca nie może wtedy powołać się na swój urzędowy zakres działania, jeśli tak kwalifikowanego zezwolenia nie uzyskał. Gdy chodzi o formę zezwolenia, to (może ono mieścić się i w rozkazie, poleceniu itd.) może nastąpić ustnie lub na piśmie.

W 2002 r., odnosząc się do oceny art. 2 rozporządzenia Prezydenta RP z 1934 r., stwierdziłem: „Współpraca miałaby odbywać się pod kontrolą służb specjalnych, byłaby sui generis kontratypem. Warto merytorycznie rozważyć ewentualne korzyści dla bezpieczeństwa państwa wynikające z wprowadzenia takiego rozwiązania, które chroniłoby osoby realizujące zadania zlecone przez polskie służby specjalne przed ewentualnymi działaniami lustracyjnymi"15.

Dekret z dnia 16 listopada 1945 r. o przestępstwach szczególnie niebezpiecznych w okresie odbudowy Państwa ${ }^{16}$ uchylił mocą prawną rozporządzenia Prezydenta Rzeczypospolitej z dnia 24 października 1934 r. o niektórych przestępstwach przeciwko bezpieczeństwu Państwa.

Warto zwrócić uwagę na pogląd B. Zająca ${ }^{17}$, że

Być może należałoby zastanowić się nad propozycją przywrócenia w naszym prawodawstwie norm określających polski organ państwowy władny zezwolić na nieprzestępne przyjęcie przez Polaka oferty współpracy z obcym wywiadem. Ongiś, gdy nasilała się szpiegowska i irredentystyczna działalność obydwu sąsiadów, na wniosek ówczesnego Oddziału II Sztabu Głównego WP klauzula taka została wprowadzona do rozporządzenia.

14 L. Peiper, Komentarz do kodeksu karnego i prawa o wykroczeniach, Kraków 1936, s. 669.

15 S. Hoc, Przestęstwa przeciwko Rzeczypospolitej Polskiej, Opole 2002, s. 114.

16 Dz.U. Nr 53, poz. 300.

17 B. Zając, Wszyscy szpiegowaliśmy wszystkich, „Rzeczpospolita” 13 stycznia 1998 r. 
W innym artykule stwierdzono, że:

„W naszej sytuacji powinniśmy sie zastanowić np. nad powrotem do norm regulujących zasady przyznawania zezwoleń na przyjmowanie przez Polaków ofert współpracy od obcych wywiadów, współpracy pod kontrolą polskiego kontrwywiadu. Rzecz jasna z wykluczeniem przestępności owej współpracy" ${ }^{18}$. Autorzy powołali się na art. 2 rozporządzenia Prezydenta z 24 października 1934 r. o niektórych przestępstwach przeciwko bezpieczeństwu Państwa.

3. W dniu 26 stycznia 2007 r. posłowie PO złożyli w Sejmie projekt ustawy o czynnościach operacyjno-rozpoznawczych (druk nr 1570), który w dniu 30 marca 2007 r. został skierowany do pierwszego czytania do Komisji Administracji i Spraw Wewnętrznych, Komisji Finansów Publicznych, Komisji Obrony Narodowej oraz Komisji Sprawiedliwości i Praw Człowieka ${ }^{19}$. W piśmie z dnia 8 marca 2007 r. Krajowa Rada Sądownictwa zaopiniowała projekt ustawy o czynnościach operacyjno-rozpoznawczych z dnia 26 stycznia 2007 r. (druk nr 1570) - bez uwag. Jednocześnie Minister Spraw Wewnętrznych i Administracji na podstawie zarządzenia nr 53 z dnia 4 lipca 2007 r. powołał zespół do opracowania projektu ustawy o pracy operacyjnej. Do zadań zespołu należało w szczególności:

— dokonanie analizy obecnie obowiązujących rozwiązań prawnych dotyczących czynności operacyjno-rozpoznawczych, w tym aktów prawnych innych państw,

- przygotowanie wstępnych założeń projektu ustawy o pracy operacyjnej,

- opracowanie harmonogramu prac nad projektem ustawy o pracy operacyjnej,

— opracowanie projektu ustawy o pracy operacyjnej, który w szczególności określiłby zagadnienia: celów pracy operacyjnej, form i metod pracy operacyjnej i dokumentowania tych czynności oraz nadzoru nad pracą operacyjną.

W dniu 31 stycznia 2008 r. zarządzeniem nr 15 Ministra Spraw Wewnętrznych i Administracji został rozszerzony skład zespołu. W trakcie jego prac przygotowano roboczy projekt ustawy o czynnościach operacyjno-rozpoznawczych.

W dniu 7 lutego 2008 r. posłowie PO złożyli w Sejmie projekt ustawy o czynnościach operacyjno-rozpoznawczych (druk nr 353) - identyczny w treści z projektem zawartym w druku nr 1570. Dnia 22 kwietnia 2008 r. projekt ustawy został skierowany do Komisji Administracji i Spraw Wewnętrznych z zaleceniem zasięgnięcia opinii Komisji do spraw Służb Specjalnych, Komisji Obrony Narodowej oraz Komisji Sprawiedliwości i Praw Człowieka. Pierwsze czytanie odbyło się w dniu 27 maja 2008 r. Powołano na nim podkomisję nadzwyczajną pod przewodnictwem M. Biernackiego (PO) — upoważnionego przez wnioskodawców

18 P. Ambroziewicz, B. Zając, Szpieg koncesjonowany, „Gazeta Sądowa” 1998, nr 3, s. 21.

19 M. Biernacki, Mętna woda specstużb, „Gazeta Wyborcza”, 9 sierpnia 2007 r. Por. także A. Taracha, O „Projekcie ustawy o czynnościach operacyjno-rozpoznawczych”, „Annales Universitatis Mariae Curie-Skłodowska" LVI/LVII, sec. G 2009/2010, s. 163-179. 
do ich reprezentowania. Podkomisja podjęła prace, które są na etapie wstępnym, z przyczyn obiektywnych (zaangażowanie jej przewodniczącego w komisji śledczej). Autor był jednym z ekspertów podkomisji.

Podczas prac podkomisji przedstawiciele strony rządowej zgłosili m.in. następujące propozycje dotyczące szpiega koronnego ${ }^{20}$ :

Artykuł 12.1. Jeżeli w trakcie realizacji przez podmioty uprawnione ich ustawowych zadań uzyskane zostaną informacje lub materiały wskazujące na uzasadnione podejrzenie popełnienia przestępstwa szpiegostwa lub o charakterze terrorystycznym oraz jego sprawcę, a jest to uzasadnione względami istotnymi z punktu widzenia interesu państwa, kierownik właściwego podmiotu uprawnionego może odstąpić od zawiadomienia właściwego prokuratora.

2. Kierownik właściwego podmiotu uprawnionego, z zastrzeżeniem ust. 4 i 5, podejmuje decyzję, o której mowa w ust. 1, w przypadku, gdy sprawca przestępstwa:

1) ujawnił wszelkie okoliczności popełnionego czynu,

2) zobowiązał się do podjęcia niejawnej współpracy z właściwym podmiotem uprawnionym.

3. Przepisu ust. 1 nie stosuje się w przypadku, gdy sprawca przestępstwa:

1) popełnił zbrodnię przeciwko życiu lub inne przestępstwo umyślne, którego skutkiem jest śmierć człowieka, ciężki uszczerbek na zdrowiu, albo współdziałał w popełnieniu takiego przestępstwa lub usiłował je popełnić, albo

2) nakłaniał osobę do popełnienia czynu zabronionego, o którym mowa w pkt 1.

4. W przypadku, gdy sprawca przestępstwa nie podjął lub pomimo podjęcia niejawnej współpracy z podmiotem uprawnionym popełnił jedno z przestępstw, o którym mowa w ust. 3, lub podejmie współdziałanie w popełnieniu takiego przestępstwa, albo będzie nakłaniał do jego popełnienia, kierownik podmiotu uprawnionego powiadamia właściwego prokuratora.

5. Kierownik podmiotu uprawnionego powiadamia właściwego prokuratora także w przypadku, gdy zostanie ujawnione, że sprawca przestępstwa, który podjął niejawną współpracę z podmiotem uprawnionym, umyślnie nie ujawnił wszelkich okoliczności czynu, o którym mowa w ust. 1, albo działa nadal na szkodę Rzeczypospolitej Polskiej.

Artykuł 18.1. Nie popełnia przestępstwa, o którym mowa w art. $130 \S 1-3$ k.k., kto dopuszcza się czynów określonych w tych przepisach, działając na zlecenie i pod kontrolą służby specjalnej w rozumieniu odrębnych przepisów, w celu realizacji ustawowych zadań tej służby, a także ten, kto zleca lub kontroluje dokonanie tych czynów lub udziela pomocy przy ich dokonaniu.

2. Nie popełnia przestępstwa, przestępstwa skarbowego, wykroczenia lub wykroczenia skarbowego kto, na zlecenie i pod kontrolą służby specjalnej w rozumieniu odrębnych przepisów, biorąc udział w obcym wywiadzie, działając na jego rzecz, dopuszcza się czynu zabronionego przez ustawę pod groźbą kary, jeżeli naruszenie prawa było konieczne dla skutecznego wykonywania czynności operacyjno-rozpoznawczej służącej realizacji ustawowych zadań tej służby.

3. Przepisu ust. 2 nie stosuje się w przypadku, gdy sprawca popełnił umyśle przestępstwo, którego skutkiem jest śmierć człowieka lub ciężki uszczerbek na zdrowiu, lub ciężki rozstrój zdrowia.

20 S. Hoc, Działanie w ramach uprawnień lub obowiazków a zasada proporcjonalności, [w:] Zasada proporcjonalności w prawie karnym, red. T. Dukiet-Nagórska, Warszawa 2010, s. 209-210. 
Zgłoszono również propozycję dotyczącą agenta specjalnego ${ }^{21}$ :

Artykuł 10.1. W uzasadnionych przypadkach, gdy jest to konieczne dla skutecznego rozpoznawania, zapobiegania i wykrywania przestępstw: szpiegostwa, o charakterze terrorystycznym, handlu ludźmi, godzących w interesy ekonomiczne państwa oraz innych przestępstw związanych z działalnością zorganizowanych grup lub związków przestępczych, funkcjonariusze lub osoby udzielające pomocy mogą za ich zgodą wykonywać niejawne zadania na rzecz podmiotów uprawnionych, działając w ramach zorganizowanych grup lub związków przestępczych.

2. Przepis ust. 1 stosuje się odpowiednio w przypadku, gdy wykonywanie niejawne zadań na rzecz podmiotu uprawnionego przez funkcjonariusza lub osobę udzielającą pomocy jest konieczne dla skutecznego rozpoznawania lub przeciwdziałania zagrożeniom zewnętrznym godzącym w bezpieczeństwo, obronność, niepodległość lub nienaruszalność terytorium Rzeczypospolitej Polskiej, a także dla skutecznego rozpoznawania międzynarodowego terroryzmu lub międzynarodowych grup przestępczości zorganizowanej i polega na braniu udziału w obcym wywiadzie lub działaniu na jego rzecz albo działaniu w grupie lub związku przestępczym.

3. Nie popełnia przestępstwa kto, działając w celu uchylenia zagrożenia realizacji czynności operacyjno-rozpoznawczych, poświęca dobro chronione prawem, jeżeli zagrożenia nie można inaczej uniknąć, a dobro poświęcone przedstawia wartość oczywiście niższą od dobra ratowanego.

4. Przepisu ust. 3 nie stosuje się w przypadku, gdy sprawca popełnił umyślne przestępstwo, którego skutkiem jest śmierć człowieka, ciężki uszczerbek na zdrowiu lub ciężki rozstrój zdrowia.

5. Decyzję o podjęciu i wykonywaniu czynności, o których mowa w ust. 1, podejmuje kierownik podmiotu uprawnionego, po uzyskaniu zgody Prokuratora Generalnego, na podstawie postanowienia Sądu Apelacyjnego w Warszawie lub Wojskowego Sądu Okręgowego w Warszawie.

4. W związku z propozycjami wprowadzenia kontratypu szpiega koronnego należy zwrócić uwagę na zasadę legalizmu i oportunizmu. Zasada legalizmu to dyrektywa, w myśl której organ procesowy, powołany do ścigania przestępstw, zobowiązany jest, $\mathrm{z}$ chwilą powzięcia uprawdopodobnionej wiadomości o przestępstwie ściganym z oskarżenia publicznego, wszcząć i przeprowadzić postępowanie karne. Przeciwstawną dyrektywą jest zasada oportunizmu, w myśl której organ procesowy może nie wszczynać postępowania, jeśli wzgląd na interes publiczny (społeczny) czyni w danej sprawie postępowanie karne z oskarżenia publicznego niecelowym ${ }^{22}$.

Zasada legalizmu materialnego ${ }^{23}$ została zdefiniowana w art. 10 § 1 i 2 k.p.k. Istotę legalizmu wyraża $\S 2$ tego przepisu, stanowiący, że z wyjątkiem wypadków określonych w ustawie lub prawie międzynarodowym nikt nie może być zwolniony od odpowiedzialności za popełnione przestępstwo. Prawo zna jednak wyjątki na rzecz oportunizmu. Jednym z takich wyjątków jest instytucja świadka koron-

21 Ibidem, s. 207-208.

22 S. Waltoś, P. Hofmański, Proces karny. Zarys systemu, Warszawa 2013, s. 286.

23 Ibidem, s. 289. 
nego, przewidziana w ustawie z dnia 25 czerwca 1997 r. o świadku koronnym ${ }^{24}$. Umarza się postępowanie przeciwko sprawcy przestępstwa z zakresu przestępczości zorganizowanej lub wymienionych w katalogu enumeratywnie wyliczonych przestępstw popełnianych w ramach przestępczości zorganizowanej (art. 1 ustawy), jeżeli złożył przed sądem wyczerpujące zeznania dotyczące osób uczestniczących w przestępstwie, które mogły się przyczynić do ujawnienia okoliczności przestępstwa, wykrycia pozostałych sprawców, ujawnienia dalszych przestępstw lub im zapobieżenia. Procedura prowadząca do nadania statusu świadka koronnego podejrzanemu jest bardzo długa: od wniosku prokuratora po uzyskaniu zgody Prokuratora Generalnego, poprzez przesłuchanie przez sąd, któremu ustawa zastrzegła wyłączność dopuszczenia dowodu z zeznań świadka koronnego, do decyzji o nadaniu tego statusu.

Odstąpienie od ścigania karnego takiego podejrzanego jest więc oportunistyczną zapłatą za dostarczenie dowodu, bez którego skazanie innych sprawców nie byłoby możliwe, a w każdym razie byłoby bardzo trudne ${ }^{25}$.

Zdaniem K. Marszała ${ }^{26}$ dopuszczalność przypadków oportunizmu, uzasadnianych ważnym interesem państwa, może doprowadzić do sytuacji, gdy organy nie będą mogły oprzeć się pokusie, by za zasłoną „interesu Państwa” ukrywać przypadki zaniechania ścigania określonych osób ze względów politycznych (z racji zajmowanych przez nich stanowisk).

T. Grzegorczyk ${ }^{27}$ podkreśla, że polski system prawa karnego tradycyjnie opiera się na zasadzie legalizmu, a rzeczywiste prawne odstępstwa oportunistyczne od zasady legalizmu w polskim systemie prawa karnego mają niewielki zakres.

J. Tylman ${ }^{28}$ uważa, że z zasadą oportunizmu w RFN wiąże się przede wszystkim kompleks norm zawartych w dwunastu paragrafach kodeksu postępowania karnego od 153 do $154 \mathrm{e}$ - otwierających dodatkowe możliwości zaniechania ścigania. Do jednej z grup zalicza się sytuacje, gdy ustawodawca uznaje, że interes realizacji ścigania karnego powinien ustąpić wobec innych interesów państwowych, z którymi znajduje się w kolizji — § 153d, 153e, 154c, 154d, 154e.

24 Dz.U. z 2016 r. poz. 1197. Por. szerzej E. Kowalewska-Borys, Świadek koronny w ujęciu dogmatycznym, Kraków 2004; J. Paśkiewicz, Instytucja świadka koronnego w ustawodawstwie amerykańskim, włoskim i niemieckim, Toruń 2006; M. Gabriel-Węglowski, Ustawa o świadku koronnym. Komentarz. Zarys instytucji w Europie, Warszawa 2011; Ustawa o świadku koronnym. Komentarz, red. A. Ważny, Warszawa 2013.

25 S. Waltoś, P. Hofmański, op. cit., s. 231.

${ }^{26}$ K. Marszał, Proces karny. Zagadnienia ogólne, Katowice 2008, s. 78.

27 T. Grzegorczyk, J. Tylman, Polskie postepowanie karne, Warszawa 2014, s. 122 n.

28 J. Tylman, Oportunizm w postępowaniu karnym Republiki Federalnej Niemiec, NP 1989, nr 10-12, s. 98; Stratprozessordnung — StPO — ustawa z 1 lutego 1877 r. obowiązuje publikacja z 7 kwietnia 1987 r. (BGBI) 1987.I., s. 1074; aktem integralnie związanym z StPO jest ustawa o organizacji sądownictwa z 21 stycznia 1877 r. (das Gerichtsverfassunsgesetz) w wersji z 9 maja 1975 r., BGBI 1975, I., s. 1077. 
Zdaniem S. Waltosia ${ }^{29} \S 153-154$ k.p.k. RFN wyrażają de facto zasadę oportunizmu.

M. Rogacka-Rzewnicka ${ }^{30}$ zauważa, że w RFN zakres ustawowych i pozaustawowych odstępstw od zasady legalizmu osiągnął takie rozmiary, że według dość powszechnej opinii trudno twierdzić, iż w systemie tym legalizm i oportunizm stanowią odpowiednio zasadę i wyjątek.

Zgodnie z § 152 StPO do wnoszenia publicznego oskarżenia jest uprawniona prokuratura (ust. 1), a według $\S 2$ „O ile ustawa nie stanowi inaczej, prokuratura jest obowiązana podjąć ściganie wszystkich przestępstw, jeżeli istnieją dostateczne ku temu przesłanki faktyczne"31.

Według § 153c ust. 1 pkt 1-3 StPO (Nieściganie czynów popełnionych za granicą) prokuratura może odstąpić od ścigania przestępstw, które: 1 . zostały popełnione poza granicami obowiązywania ustawodawstwa RFN, 2. popełnił je cudzoziemiec w kraju na pokładzie obcego samolotu, 3. Spowodowały już wykonanie wymierzonej za granicą kary, a kara spodziewana w kraju, po zaliczeniu kary wymierzonej za granicą, nie miałaby znaczenia, albo co do których osoba ścigana została już za granicą prawomocnie uniewinniona. Prokuratura ponadto może odstąpić od ścigania przestępstw popełnionych w kraju, jeżeli działalność przestępcza wykonywana była również za granicą, a przeprowadzenie postępowania mogłoby spowodować poważną szkodę dla RFN bądź jeśli inne istotne interesy o charakterze publicznym przemawiają przeciwko ściganiu. Przepis przewiduje także, że w niektórych z wymienionych sytuacji prokuratura może, już po wniesieniu skargi, cofnąć ją i umorzyć postępowanie ${ }^{32}$.

Przepis § 153d StPO (Odstąpienie od ścigania ze względów politycznych) upoważnia prokuratora generalnego RFN do zaniechania ścigania niektórych przestępstw skierowanych przeciwko bezpieczeństwu państwa (powodujących zagrożenie demokratycznego i praworządnego państwa lub zagrożenie obronności kraju), jeżeli ściganie mogłoby spowodować poważną szkodę w interesach RFN albo gdy przeciwko ściganiu przemawiają poważne interesy publiczne. Prokurator generalny może umorzyć postępowanie także po wniesieniu skargi, uprzednio wycofując ją z sądu.

Należy zauważyć, iż w $§ 153 \mathrm{~d}$ StPO chodzi m.in. o przestępstwa zagrożenia obronności kraju, zdrady stanu, zdrady kraju i zagrożenia bezpieczeństwa zewnętrznego.

29 S. Waltoś, P. Hofmański, op. cit., s. 288.

30 M. Rogacka-Rzewnicka, Oportunizm i legalizm ścigania przestępstw w świetle współczesnych przeobrażé́ procesu karnego, Warszawa 2007, s. 113.

31 J. Schulenburg, Zasady legalizmu i oportunizmu w niemieckim kodeksie postępowania karnego - zależności i sprzeczności, Prok. i Pr. 2003, nr 5, s. 90.

32 J. Tylman, op. cit., s. $101 \mathrm{n}$. 
Paragraf 153e StPO (Odstąpienie od skargi przy czynnym żalu) dotyczy tego samego kręgu przestępstw, który obejmuje $\S 153 \mathrm{~d}$, i upoważnia prokuratora generalnego RFN, lecz za zgodą właściwego wyższego sądu krajowego (Oberlandesgericht), do odstąpienia od ściągania i umorzenia postępowania, jeżeli sprawca po dokonaniu czynu, zanim dowiedział się o jego ujawnieniu, przyczynił się do odwrócenia niebezpieczeństwa grożącego całości bezpieczeństwu RFN lub jej konstytucyjnemu porządkowi. Takie odstąpienie od wniesienia skargi dopuszczalne jest również wówczas, gdy sprawca czynu przekaże odpowiedniemu organowi pełne informacje na temat swoich działań i związanych z nimi okoliczności. Po wniesieniu skargi w tych samych warunkach może umorzyć postępowanie — za zgodą prokuratora generalnego RFN — właściwy wyższy sąd krajowy.

5. W dniu 10 czerwca 2016 r. Sejm uchwalił ustawę o działaniach antyterrorystycznych $^{33}$, która określa zasady prowadzenia działań antyterrorystycznych oraz współpracy między organami właściwymi w zakresie prowadzenia tych działań.

Według art. 2 pkt 2 przez działania kontrterrorystyczne należy rozumieć działania wobec sprawców, osób przygotowujących lub pomagających w dokonaniu przestępstwa o charakterze terrorystycznym, o którym mowa w art. 115 § 20 ustawy z dnia 6 czerwca 1997 r. — Kodeks karny (Dz.U. Nr 88, poz. 553 z późn. zm.), prowadzone w celu wyeliminowania bezpośredniego zagrożenia życia, zdrowia lub wolności osób lub mienia przy wykorzystaniu specjalistycznych sił i środków oraz specjalistycznej taktyki działania, natomiast według art. 2 pkt 7 przez zdarzenie o charakterze terrorystycznym należy rozumieć sytuację, co której istnieje podejrzenie, że powstała na skutek przestępstwa o charakterze terrorystycznym, o którym mowa w art. 115 § 20 ustawy z dnia 6 czerwca 1997 r. — Kodeks karny, lub zagrożenie zaistnienia takiego przestępstwa.

Na podstawie ustawy o działaniach antyterrorystycznych znowelizowano m.in. ustawę z dnia 24 maja 2002 r. o ABW oraz AW, dodając art. 22b. Według art. $22 \mathrm{~b}$ ust. 1 jeżeli informacje lub materiały uzyskane przez ABW podczas realizacji zadań, o których mowa w art. 5 ust. 1: 1) wskazują na popełnienie przestępstwa szpiegostwa albo 2) uprawdopodobniają działalność zmierzającą do popełnienia przestępstwa o charakterze terrorystycznym — Szef ABW może, w przypadku gdy jest to uzasadnione względami bezpieczeństwa państwa, odstąpić od obowiązku zawiadomienia właściwego prokuratora o uzasadnionym podejrzeniu popełnienia tego przestępstwa oraz osobie, która według uzyskanych przez ABW informacji lub materiałów może być jego sprawcą. Szef ABW może odstąpić od tego obowiązku, w przypadku gdy sprawca przestępstwa szpiegostwa albo podejrzewany o przestępstwa o charakterze terrorystycznym świadomie i dobrowolnie: 1) ujawnił wszelkie okoliczności popełnionego czynu lub prowadzonej działalności, 2) zobowiązał się do podjęcia tajnej współpracy z ABW (art. 22b ust. 2).

33 Dz.U. poz. 904. 
Trzeba zauważyć, iż do zadań $\mathrm{ABW}^{34}$ należy, według art. 5 ust. 1 pkt 1 , rozpoznawanie, zapobieganie i zwalczanie zagrożeń godzących w bezpieczeństwo wewnętrzne państwa oraz jego porządek konstytucyjny, a w szczególności w suwerenność i międzynarodową pozycję, niepodległość i nienaruszalność jego terytorium, a także obronność państwa, a według pkt 2 - rozpoznawanie, zapobieganie i wykrywanie przestępstw szpiegostwa, terroryzmu, bezprawnego ujawniania lub wykorzystywania informacji niejawnych i innych przestępstw godzących w bezpieczeństwo państwa oraz ściganie ich sprawców.

W ABW zwalczaniem szpiegostwa zajmują się Departament Kontrwywiadu i Departament Postępowań Karnych, a terroryzmu - Departament Zwalczania Terroryzmu i Zagrożeń Strategicznych oraz Centrum Antyterrorystyczne, a także Departament Postępowań Karnych ${ }^{35}$.

Należy zauważyć, że przestępstwo szpiegostwa zostało stypizowane w art. 130 k.k. ${ }^{36}$ Przestępstwo szpiegostwa może być popełnione przez:

— branie udziału w działalności obcego wywiadu przeciwko RP,

— branie udziału w obcym wywiadzie albo działanie na rzecz obcego wywiadu przez udzielenie mu wiadomości, których przekazanie może wyrządzić skodę RP,

— gromadzenie lub przechowywanie wiadomości w celu udzielenia obcemu wywiadowi,

— włączanie się do sieci komputerowej w celu uzyskania wiadomości,

— zgłoszenie gotowości działania na rzecz obcego wywiadu przeciwko RP,

34 Dz.U. z 2015 r. poz. 1929 ze zm.

35 M.P. z 2014 r. poz. 203; z 2015 r. poz. 315.

36 Por. np. S. Hoc, Przestepstwa przeciwko Rzeczypospolitej Polskiej, Opole 2002, s. 44 n.; idem [w:] Prawo karne. Część ogólna, szczególna i wojskowa, red. T. Dukiet-Nagórska, Warszawa 2016, s. 300 n.; idem, Przestepstwa przeciwko Rzeczypospolitej Polskiej, [w:] System Prawa Karnego, t. 8. Przestepstwa przeciwko państwu i dobrom zbiorowym, red. L. Gardocki, Warszawa 2013, s. 70-129; idem, Komentarz do art. 130 k.k., [w:] Kodeks karny. Komentarz, t. 2, red. R.A. Stefański, Warszawa 2015, s. 777-783; idem, O szpiegostwie w ustawodawstwie karnym II Rzeczypospolitej, „Opolskie Studia Administracyjno-Prawne” 2012, X/1, s. 35-47; idem, Artykut 130 k.k. — czy istnieje potrzeba nowelizacji?, [w:] Granice kryminalizacji i penalizacji, red. S. Pikulski, M. Romańczuk-Grącka, Olsztyn 2013, s. 249-266; idem, Ściganie i karanie sprawców szpiegostwa, [w:] Meandry prawa karnego i kryminalistyki. Księga jubileuszowa prof. zw. dra hab. Stanisława Pikulskiego, red. nauk. J. Kasprzak, W. Cieślak, I. Nowicka, Szczytno 2015, s. 89-102; M. Bojarski [w:] Prawo karne materialne. Część ogólna i szczególna, red. M. Bojarski, Warszawa 2015, s. 433; L. Gardocki, Prawo karne, Warszawa 2015, s. 212; P. Kardas [w:] Kodeks karny. Część szczególna, t. II, red. A. Zoll, Warszawa 2013, s. 121-140; J. Wojciechowska [w:] Kodeks karny. Część szczególna, t. I, red. A. Wąsek, R. Zawłocki, Warszawa 2010, s. 73-80; J. Kulesza, Przestępstwa przeciwko Rzeczypospolitej Polskiej, [w:] Kodeks karny. Część szczególna, t. 1. Komentarz. Art. 117-221, red. M. Królikowski, R. Zawłocki, Warszawa 2013, s. 81-91; P. Hofmański [w:] Kodeks karny. Komentarz, red. M. Filar, Warszawa 2016, s. 885-888; K. Wiak [w:] Kodeks karny. Komentarz, red. A. Grześkowiak, K. Wiak, Warszawa 2012, s. 718-720; A. Marek, V. Konarska-Wrzosek, Prawo karne, Warszawa 2016, s. 438-441. 
— organizowanie lub kierowanie działalnością obcego wywiadu.

Jest to wyliczenie taksatywne. Należy zauważyć, iż w art. $130 \S 4$ k.k. popełniono usterkę legislacyjną, gdyż nie wskazano, że chodzi o organizowanie lub kierowanie działalnością obcego wywiadu przeciwko RP. Zgłaszane były postulaty zmiany, lecz bezskutecznie. Interpretacja tego przepisu musi być zawężająca, uwzględniająca poprzednie paragrafy i tytuł rozdziału. Należy zauważyć, iż poza uwagą dotyczącą art. $130 \S 4$ k.k. nie ma merytorycznego i aktualnego uzasadnienia podjęcia prac nowelizacyjnych.

Według art. $115 \S 20$ k.k. przestępstwem o charakterze terrorystycznym jest czyn zabroniony, zagrożony karą pozbawienia wolności, której górna granica wynosi co najmniej 5 lat, popełniony w celu:

1) poważnego zastraszenia wielu osób,

2) zmuszenia organu władzy publicznej Rzeczypospolitej Polskiej lub innego państwa albo organu organizacji międzynarodowej do podjęcia lub zaniechania określonych czynności,

3) wywołania poważnych zakłóceń w ustroju lub gospodarce Rzeczypospolitej Polskiej, innego państwa lub organizacji międzynarodowej

— a także groźba popełnienia takiego czynu ${ }^{37}$.

O przestępstwie o charakterze terrorystycznym mowa jest w ośmiu przepisach kodeksu karnego. W art. 65 § 1 k.k., zgodnie z którym wobec sprawcy takiego przestępstwa stosuje się specyficzne regulacje dotyczące wymiaru kary, środków karnych oraz środków związanych z poddaniem próbie, przewidziane w razie recydywy szczególnej wielokrotnej (art. 64 § 2 k.k.).

Terrorystyczny charakter przestępstwa jest przesłanką stosowania polskiej ustawy karnej do cudzoziemca, który popełnił je za granicą (art. $110 \S 1$ k.k.), występuje jako znamię sześciu typów czynów zabronionych: art. 165a — sfinansowanie przestępstwa o charakterze terrorystycznym, art. $240 \S 1$ - niezawiadomienie o przestępstwie o charakterze terrorystycznym, art. 255a k.k. — rozpowszechnianie treści mogących ułatwić popełnienie przestępstwa o charakterze terrorystycznym lub udział w szkoleniu mogącym umożliwić popełnienie takiego przestępstwa, art. $258 \S 2$ i 4 k.k. — zorganizowana grupa i związek przestępczy, art. 259a k.k. - przekraczanie granicy RP w celu popełnienia przestępstwa o charakterze terrorystycznym lub przestępstwa określonego w art. 255a lub art. 258 § lub 4.

Zdaniem K. Wiaka ${ }^{38}$ definicja przestępstwa o charakterze terrorystycznym jest dwusegmentowa. Po pierwsze, na podstawie kryterium formalnego ustawodawca wyznaczył katalog czynów zabronionych, zagrożonych karą pozbawienia wolności, której górna granica wynosi co najmniej 5 lat. Warunek ustawowego zagrożenia karą spełnia ponad 200 tytułów czynów określonych w części szcze-

37 S. Hoc, O penalizacji przestępstw o charakterze terrorystycznym, „Wojskowy Przegląd Prawniczy" 2004, nr 4, s. 3 n.

38 K. Wiak [w:] Kodeks karny. Komentarz, red. A. Grześkowiak, K. Wiak, s. 673-674. 
gólnej k.k. Drugi element definicji wprowadza kryterium materialne, wymagające stwierdzenia u sprawcy zamiaru podbudowanego dodatkowymi przeżyciami psychicznymi w postaci dążenia do realizacji jednego z trzech celów wymienionych w art. $115 \S 20$ k.k. Oba składniki definicji — formalny i materialny — muszą wystąpić łącznie. Autor trafnie podkreśla, że ustawodawca pominął w definicji odniesienia do motywacji, jaka skłania sprawcę do popełnienia czynu zabronionego, czyli „odpolityczniono” normatywną ocenę przestępstw o charakterze terrorystycznym, w którego zakresie mieszczą się nie tylko przejawy terroryzmu politycznego, lecz także przypadki tzw. terroryzmu kryminalnego. W ramach kompleksowej strategii ustawodawca dokonał kryminalizacji czynów popełnianych „na przedpolu” właściwego przestępstwa o charakterze terrorystycznym ${ }^{39}$.

Kompetencja Szefa ABW, określona w ust. 1 i 2 art. 22b, jest fakultatywna, lecz powinna być uzasadniona względami bezpieczeństwa państwa. Formuła „bezpieczeństwo państwa” została zamieszczona wśród ogólnych przesłanek ograniczenia praw i wolności, wymienionych w art. 31 ust. 3 Konstytucji RP, a także w art. 45 ust. 2, art. 53 ust. 3 oraz art. 61 ust. 3. Zdaniem TK ,przesłanka bezpieczeństwo państwa obejmuje zarówno konieczność ochrony przed zagrożeniami zewnętrznymi, jak i wewnętrznymi, a także oznacza wolność od zagrożeń dla istnienia państwa demokratycznego" 40 .

TK w wyroku z dnia 16 lutego 1999 r. SK 11/98 uznał bezpieczeństwo państwa za wartość, która w każdym demokratycznym porządku prawnym może, w granicach wyznaczonych niezbędnością, uzasadniać wkroczenie w prawa jednostki ${ }^{41}$.

Przyjmuje się, że bezpieczeństwo państwa to „stan niezagrożenia umożliwiający państwu (narodowi) bezpieczną egzystencję i rozwój”42. Warto zauważyć, iż ustawodawca wprowadził w art. 25 ust. 1 ustawy o działaniach antyterrorystycznych pojęcie osoby podejrzewanej (przepisy szczególne dotyczące postępowania przygotowawczego) i pojęcie „podejrzewany” do art. 22b ust. 2, 6, 10 ustawy o ABW oraz AW. Pojęcia te nie są znane na gruncie procesu karnego (art. $71 \S 1$ k.p.k.), może wywoływać to wątpliwości interpretacyjne. W art. 131 k.k. mowa jest o „Wszystkich istotnych okolicznościach popełnionego czynu” natomiast w art. 22 b ust. 2 „o wszelkich okolicznościach popełnionego czynu lub prowadzonej działalności”. Działanie sprawcy ma być świadome i dobrowolne, wymóg ten odnosi się do ujawnienia. Pobudki jego działania są obojętne. W języku potocznym słowo „dobrowolnie” jest przysłówkiem od „dobrowolny”, ten zaś oznacza: 1) 'wynikający z własnej woli, nieprzymuszony bez przymusu', 2) dawniejsze

\footnotetext{
39 Ibidem, s. 675.

40 Wyrok TK z dnia 21 czerwca 2005 r., P. 25/02., OTK-A 2005, nr 6, poz. 65.

41 OTK 1999, nr 2, poz. 22.

42 W.J. Wołpiuk, Sity zbrojne w regulacjach Konstytucji RP, Warszawa 1998, s. 47.
} 
'dobroduszny', 'łagodny’43. Z tego wyjaśnienia nie wynika więc, aby dobrowolnie działał ten, którego motywy oceniamy dodatnio pod względem moralnym. Ujawnienie jest spontanicznym aktem woli sprawcy, który dobrowolnie i samorzutnie, nie pod wpływem przedstawionych mu dowodów przestępczej działalności, ujawnia wszelkie okoliczności (nie tylko istotne) popełnionego czynu lub prowadzonej działalności. O tym, czy przedstawione przez sprawcę okoliczności są wszelkie, decydować będzie Szef ABW. Sprawca, chcący skorzystać z przepisu art. 22b ustawy o ABW oraz AW, powinien, oprócz ujawnienia roli, jaką odgrywał oraz swej działalności już dokonanej lub zamierzonej, ujawnić wszystkie znane mu osoby, z którymi współpracował, i ich czyny przestępne oraz poinformować o środkach służących do popełnienia tych czynów. Chodzi tu np. o poznanie metod i form pracy obcego wywiadu, jego organizacji, systemu szkolenia i łączności, zakresu zainteresowań, sposobów opracowywania wiadomości i ich wykorzystywania itp. Jest to podyktowane względami bezpieczeństwa państwa, ochrony jego interesów, a także, w pewnej mierze, potrzebą i koniecznością ciągłego rozpoznawania obcej penetracji wywiadowczej i przeciwdziałania jej. Kolejnym wymogiem jest zobowiązanie się do tajnej współpracy z ABW. Celem tajnej współpracy będzie m.in. ustalenie pracowników obcego wywiadu, poznanie środków łączności wywiadowczej, uzyskanie dowodów przestępczej działalności, dezinformacja, gra operacyjna.

Z art. 36 ust. 1 ustawy o ABW oraz AW wynika, że „Agencje przy wykonywaniu swoich zadań mogą korzystać, z zastrzeżeniem art. 37, z pomocy osób niebędących ich funkcjonariuszami. Zabronione jest, z zastrzeżeniem ust. 2, ujawnianie danych o osobie udzielającej Agencji pomocy przy wykonywaniu czynności operacyjno-rozpoznawczych". Nie wiadomo jednak, o jaką współpracę chodzi jawną czy tajną. W pierwszym zdaniu jest mowa o osobach świadczących wszelką pomoc Agencjom (tajną i jawną), w drugim o osobie „udzielającej pomocy przy wykony waniu czynności operacyjno-rozpoznawczych". Warto zwrócić uwagę, że art. 37 ust. 1 wprowadza pojęcie „tajnej współpracy”. Artykuł 36 ust. 2 stanowi, że: „Ujawnienie danych o osobie, o której mowa w ust. 1, może nastąpić jedynie w przypadkach okresowych w art. 39 ust. 4".

Przyjąć należy, że art. 39 dotyczy osób udzielających pomocy w zakresie wykonywania czynności operacyjno-rozpoznawczych. Trafny jest pogląd, że w art. 36 ust. 1 chodzi o tajną współpracę, i to w zakresie wykonywania czynności operacyjno-rozpoznawczych. Ustawa nie definiuje pojęcia tajnego współpracownika, który nie jest funkcjonariuszem ${ }^{44}$.

Art. 37.1. Agencje nie mogą przy wykonywaniu swoich zadań korzystać z tajnej współpracy:

43 Stownik języka polskiego, red. M. Szymczak, t. I, Warszawa 1978, s. 405.

44 K. Krełowski, Tajni współpracownicy ABW, MI5 oraz FSB, „Przegląd Bezpieczeństwa Wewnętrznego" 2015, nr 13, s. 41 n. 
1) posłów i senatorów;

2) osób zajmujących kierownicze stanowiska państwowe, o których mowa w art. 2 ustawy z dnia 31 lipca 1981 r. o wynagrodzeniu osób zajmujących kierownicze stanowiska państwowe (Dz.U. Nr 20, poz. 101 z poźn. zm.);

3) dyrektorów generalnych w ministerstwach, urzędach centralnych lub urzędach wojewódzkich;

4) sędziów, asesorów, prokuratorów, adwokatów i radców prawnych;

5) członków rady nadzorczej, członków zarządu oraz dyrektorów programów „Telewizji Polskiej — Spółka Akcyjna” i „Polskiego Radia — Spółka Akcyjna”, a także dyrektorów terenowych oddziałów „Telewizji Polskiej — Spółka Akcyjna";

6) dyrektora generalnego, dyrektorów biur oraz kierowników oddziałów regionalnych „Polskiej Agencji Prasowej — Spółka Akcyjna”;

7) nadawców w rozumieniu art. 4 pkt 1 ustawy z dnia 29 grudnia 1992 r. o radiofonii i telewizji (Dz.U. z 2004 r. Nr 253, poz. 2531 z późn. zm.);

8) redaktorów naczelnych, dziennikarzy lub osób prowadzących działalność wydawniczą, o których mowa w ustawie z dnia 26 stycznia 1984 r. — Prawo prasowe (Dz.U. Nr 5, poz. 24 z późn. zm.);

9) rektorów, prorektorów i kierowników podstawowych jednostek organizacyjnych w publicznych i niepublicznych szkołach wyższych;

10) członków Rady Głównej i Szkolnictwa Wyższego, Polskiej Komisji Akredytacyjnej i Centralnej Komisji do Spraw Stopni i Tytułów.

2. Szefowie Agencji w celu realizacji zadań Agencji mogą wydać zgodę na korzystanie z tajnej współpracy z osobami, o których mowa w ust. 1 pkt 7 i 8, jeżeli jest to uzasadnione względami bezpieczeństwa państwa, po uzyskaniu zgody Prezesa Rady Ministrów.

3. W przypadku powołania ministra w celu koordynowania działalności służb specjalnych Szefowie Agencji wyrażają zgodę, o której mowa w ust. 2, po uzyskaniu zgody na tego ministra.

W ustępie 1 pkt 2 znajduje się odesłanie do art. 2 ustawy z dnia 31 lipca 1981 r. o wynagrodzeniu osób zajmujących kierownicze stanowiska państwowe ${ }^{45}$, który brzmi następująco:

Art. 2. Ustawa ustala zasady wynagradzania osób zajmujących kierownicze stanowiska państwowe:

1. Prezydenta Rzeczypospolitej Polskiej;

2. Marszałka Sejmu, Marszałka Senatu, Prezesa Rady Ministrów, wicemarszałka Sejmu, wicemarszałka Senatu, wiceprezesa Rady Ministrów, Prezesa Najwyższej Izby Kontroli, ministra, Prezesa Narodowego Banku Polskiego, Rzecznika Praw Obywatelskich, Rzecznika Praw Dziecka, Generalnego Inspektora Ochrony Danych Osobowych, Prezesa Instytutu Pamięci Narodowej — Komisji Ścigania Zbrodni przeciwko Narodowi Polskiemu, Przewod-

45 Dz.U. z 2011 r. Nr 79, poz. 430 ze zm. 
niczącego Krajowej Rady Radiofonii i Telewizji, Prezesa Prokuratorii Generalnej Skarbu Państwa, wiceprezesa Najwyższej Izby Kontroli, Szefa Kancelarii Sejmu, Szefa Kancelarii Senatu, zastępcy Szefa Kancelarii Sejmu, zastępcy Szefa Kancelarii Senatu, Szefa Kancelarii Prezesa Rady Ministrów, Szefa Służby Cywilnej, Głównego Inspektora Pracy, zastępcy Głównego Inspektora Pracy, Kierownika Krajowego Biura Wyborczego;

3. Ministra Stanu, Szefa Kancelarii Prezydenta, zastępcy Szefa Kancelarii Prezydenta, zastępcy Prokuratora Generalnego, wiceprezesa Prokuratorii Generalnej Skarbu Państwa;

4. Prezesa Polskiej Akademii Nauk, sekretarza stanu, członka Krajowej Rady Radiofonii i Telewizji, pierwszego zastępcy Prezesa Narodowego Banku Polskiego, podsekretarza stanu (wiceministra), wiceprezesa Narodowego Banku Polskiego, Zastępcy Rzecznika Praw Obywatelskich, Zastępcy Rzecznika Praw Dziecka, Zastępcy Generalnego Inspektora Ochrony Danych Osobowych, Rzecznika Ubezpieczonych, kierownika urzędu centralnego, wiceprezesa Polskiej Akademii Nauk, wojewody, zastępcy kierownika urzędu centralnego, wicewojewody.

Z powyższej regulacji wynikają ograniczenia werbunkowe ABW (AW), a także SKW i SWW, CBA, które zostały wprowadzone w 2006 r. Ograniczenia takie nie znalazły się np. w ustawie o Policji, SG, ŻW, kontroli skarbowej.

Krytycznie ocenia się ograniczenia podmiotowe zawarte w ustawach o ABW oraz AW, SKW oraz SWW i CBA w zakresie prowadzenia przez te służby działalności agenturalnej przy pomocy tajnych współpracowników ${ }^{46}$.

Wątpliwości budzą definicje niektórych podmiotów, np. dziennikarzy.

Pojęcia te zostały zdefiniowane (ogólnie) w ustawie z dnia 26 stycznia 1984 r. — Prawo prasowe. Według art. 7 ust. 2 pkt 5 dziennikarzem jest osoba zajmująca się redagowaniem, tworzeniem lub przygotowywaniem materiałów prasowych, pozostająca $\mathrm{w}$ stosunku pracy $\mathrm{z}$ redakcją albo zajmująca się taką działalnością na rzecz i z upoważnienia (czyli może to być współpraca niesformalizowana prawnie — bez umowy cywilnoprawnej). Jest to więc bardzo pojemna definicja. Warto zauważyć, że materiałem prasowym jest każdy opublikowany lub przekazany do opublikowania w prasie tekst albo obraz o charakterze informacyjnym, publicystycznym, dokumentalnym lub inny niezależnie od środków przekazu, rodzaju, formy, przeznaczenia czy autorstwa ${ }^{47}$.

$\mathrm{Z}$ art. 37 powiązany jest art. 153d, który za sam fakt podjęcia współpracy z nadawcą, redaktorem naczelnym, dziennikarzem lub osobą prowadzącą działalność wydawniczą przewiduje sankcję karną do ośmiu lat pozbawienia wolności. Podjęcie współpracy z dziennikarzem jest możliwe po uzyskaniu zgody szefa ABW, poprzedzonej zgodą Prezesa Rady Ministrów, lub w przypadku powołania ministra w celu koordynowania działalności służb specjalnych, po uzyskaniu zgody tego ministra.

46 M. Bożek, Stużby specjalne oraz kryteria ich klasyfikacji na gruncie polskiego ustawodawstwa, [w:] Stużby specjalne w strukturze władz publicznych. Zagadnienia prawnoustrojowe, red. M. Bożek et al., Warszawa 2014, s. 23-24.

47 S. Hoc, P. Szustakiewicz, Ustawa o Centralnym Biurze Antykorupcyjnym. Komentarz, Baza Lex/el. 2012. 
Natomiast brytyjska ustawa o czynnościach operacyjno-rozpoznawczych z 2000 r. (Regulation of Investigatory Powers Act 2000) definiuje pojęcie „,niejawnych osobowych źródeł informacji" (covert human intelligence source) i nie wprowadza ograniczeń podmiotowych w zakresie werbunku wśród funkcjonariuszy państwowych.

W Federacji Rosyjskiej obowiązuje ustawa z 5 lipca 1995 r. o czynnościach operacyjno-rozpoznawczych, nie zawiera ona definicji tajnego współpracownika, podstawą współpracy jest umowa, niedozwolone jest podejmowanie tajnej współpracy z: deputowanymi, sędziami, prokuratorami, adwokatami, duchownymi i przewodniczącymi stowarzyszeń wyznaniowych ${ }^{48}$.

Przepisy art. 22b ustawy o ABW oraz AW mają charakter lex specialis $\mathrm{w}$ stosunku do ograniczeń werbunkowych zawartych w art. 37 ustawy o ABW oraz AW, dlatego też wobec osób wymienionych w art. 22b stosuje się regulacje w nim zawarte. Szef ABW w drodze zarządzeń określa sposoby, metody i formy wykonywania zadań Agencji w zakresie nieobjętym innymi przepisami (art. 19 ust. 3), mają one charakter najczęściej niejawny.

Na podstawie art. 5 ust. 1 pkt 5 i 6 ustawy z dnia 5 sierpnia 2010 r. o ochronie informacji niejawnych ${ }^{49}$ informacjom niejawnym nadaje się klauzulę ,ściśle tajne", jeżeli ich nieuprawnione ujawnienie spowoduje wyjątkowo poważną szkodę dla Rzeczypospolitej Polskiej przez to, że doprowadzi, lub może doprowadzić, do identyfikacji funkcjonariuszy, żołnierzy lub pracowników służb odpowiedzialnych za realizację zadań wywiadu lub kontrwywiadu, którzy wykonują czynności operacyjno-rozpoznawcze, lub może doprowadzić do identyfikacji osób udzielających im pomocy w tym zakresie oraz zagrozi, lub może zagrozić, życiu lub zdrowiu funkcjonariuszy, żołnierzy lub pracowników, którzy wykonują czynności operacyjno-rozpoznawcze lub osób udzielających im pomocy w tym zakresie.

Szef ABW może odstąpić od obowiązku, o którym mowa w art. 22b ust. 1, po zasięgnięciu opinii Prokuratora Generalnego oraz ministra-członka Rady Ministrów właściwego do spraw koordynowania działalności służb specjalnych, jeżeli został powołany. Identyczne uprawnienia nadano Szefowi SKW (art. 27a ustawy o SKW oraz SWW) ${ }^{50}$. Z istoty opinia nie ma charakteru wiążącego, lecz wydaje

48 K. Krełowski, op. cit., s. 46 n.

49 Dz.U. z 2016 r. poz. 1167; S. Hoc, Ustawa o ochronie informacji niejawnych. Komentarz, Warszawa 2010, s. 90-91.

50 Do zadań SKW należy, według art. 5 ust. 1 pkt 1, rozpoznawanie, zapobieganie oraz wykrywanie popełnionych przez żołnierzy pełniących czynną służbę wojskową, funkcjonariuszy SKW i SWW oraz pracowników SZ RP i innych jednostek organizacyjnych MON przestępstw: a) przeciwko pokojowi, ludzkości oraz przestępstw wojennych określonych w rozdziale XVI ustawy z dnia 6 czerwca 1997 r. — Kodeks karny, a także innych ustawach i umowach międzynarodowych, b) przeciwko Rzeczypospolitej Polskiej określonych w rozdziale XVII ustawy z dnia 6 czerwca 1997 r. - Kodeks karny oraz takich czynów skierowanych przeciwko państwom obcym, które zapewniają wzajemność, c) określonych w art. 140 ustawy z dnia 6 czerwca 1997 r. — Kodeks 
się, że $\mathrm{w}$ przypadku zastosowania procedury określonej $\mathrm{w}$ art. $22 \mathrm{~b}$ powinna być ona pozytywna. Odstąpienie od obowiązku, o którym mowa w art. 22b ust. 1, dotyczy funkcjonariuszy publicznych wykonujących czynności w postępowaniu określonym w tym artykule, czyli będą to funkcjonariusze ABW, np. Departamentu Kontrwywiadu i ich przełożeni. Szef ABW oraz wymienieni funkcjonariusze publiczni, wykonujący czynności w postępowaniu, o którym mowa w art. 22b ustawy o ABW oraz AW, działają w ramach obowiązków służbowych, czyli działają w granicach uprawnień i obowiązków służbowych. Warto zauważyć, iż wobec wymienionych funkcjonariuszy publicznych nie będzie miał zastosowania przepis art. 240 k.k., stanowiący o obowiązku denuncjacji; wymienia on m.in. szpiegostwo, zamach terrorystyczny, przestępstwa o charakterze terrorystycznym.

Odstąpienie od obowiązku, o którym mowa w art. 22b ust. 1, dotyczy funkcjonariuszy publicznych wykonujących czynności w postępowaniu określonym $\mathrm{w}$ art. 22b. Pojęcie funkcjonariusza publicznego zostało określone w art. 115 $\S 13$ k.k., aktualnie szefowie ABW i SKW nie są funkcjonariuszami ani żołnierzami, tylko pracownikami administracji rządowej w ujęciu art. $115 \S 13$ pkt 4 (czyli funkcjonariuszami publicznymi).

Warto zwrócić uwagę, że w art. 2 pkt 5 ustawy o działaniach antyterrorystycznych i w art. $22 \mathrm{~b}$ ust. 3 oraz art. 27a ust. 3 ustawy o SKW oraz SWW użyto określenia „Minister Koordynator Służb Specjalnych”, przez które należy rozumieć Ministra-Członka Rady Ministrów, którego zakres działania jest wyznaczony na podstawie art. 33 ust. 1 z dnia 8 sierpnia 1996 r. o Radzie Ministrów i obejmuje zadania związane z działalnością służb specjalnych, wynikające z Rozporządzenia Prezesa Rady Ministrów z dnia 18 listopada 2015 r. w sprawie szczegółowego zakresu działania Ministra-Członka Rady Ministrów Mariusza Kamińskiego Koordynatora Służb Specjalnych ${ }^{51}$.

karny, d) określonych w art. 228-230 ustawy z dnia 6 czerwca 1997 r. — Kodeks karny, jeżeli mogą one zagrażać bezpieczeństwu lub zdolności bojowej SZ RP lub innych jednostek organizacyjnych MON, e) przeciwko ochronie informacji określonych w rozdziale XXXIII ustawy z dnia 6 czerwca 1997 r. — Kodeks karny, jeżeli mogą one zagrażać bezpieczeństwu lub zdolności bojowej SZ RP lub innych jednostek organizacyjnych MON, a także takich czynów skierowanych przeciwko państwom obcym, które zapewniają wzajemność, f) określonych w art. 33 ust. 1, 2 i 3 ustawy z dnia 29 listopada 2000 r. o obrocie z zagranicą towarami, technologiami i usługami o znaczeniu strategicznym dla bezpieczeństwa państwa, a także dla utrzymania międzynarodowego pokoju i bezpieczeństwa (Dz.U. z 2013 r. poz. 194), g) innych niż określone w lit. a-f, godzących w bezpieczeństwo potencjału obronnego państwa, SZ RP oraz jednostek organizacyjnych MON, a także państw, które zapewniają wzajemność, natomiast pkt 2a stanowi: rozpoznawanie, zapobieganie oraz wykrywanie zdarzeń oraz przestępstw o charakterze terrorystycznym godzących w bezpieczeństwo potencjału obronnego państwa SZ RP oraz jednostek organizacyjnych MON. Ustawa z dnia 9 czerwca 2006 r. o Służbie Kontrwywiadu Wojskowego oraz Służbie Wywiadu Wojskowego (Dz.U. z 2016 r. poz. 1318).

51 Dz.U. poz. 1921. 
Według art. 22b ust. 5 przepisu ust. 1 nie stosuje się, gdy sprawca przestępstwa szpiegostwa lub podejrzany o przestępstwa o charakterze terrorystycznym: 1) popełnił umyślne przestępstwo przeciwko życiu albo inne przestępstwo umyślne, którego skutkiem jest śmierć człowieka, ciężki uszczerbek na zdrowiu albo 2) współdziałał w popełnieniu takiego przestępstwa lub usiłował je popełnić, albo 3) nakłaniał inną osobę do popełnienia czynu zabronionego, o którym mowa w pkt 1 . Przestępstwami wymienionymi w art. $22 \mathrm{~b}$ ust. 5 pkt 1 są przestępstwa określone w art. 163, 165, 166, 173, 177 k.k.

Według art. 22b ust. $6 \mathrm{w}$ przypadku, gdy sprawca przestępstwa szpiegostwa lub podejrzany o przestępstwa o charakterze terrorystycznym, mimo podjęcia tajnej współpracy z ABW, prowadzi nadal działalność na szkodę Rzeczypospolitej Polskie niezgodnie $\mathrm{z}$ warunkami tej współpracy albo popełnił jedno z przestępstw, o których mowa w ust. 3, lub współdziałał w popełnieniu takiego przestępstwa, albo nakłaniał do jego popełnienia, Szef ABW powiadamia o tym właściwego prokuratora.

Należy zauważyć, iż na podstawie art. 22b ust. 7 Szef ABW powiadamia właściwego prokuratora także w przypadku, gdy zostanie ujawnione, że sprawca przestępstwa szpiegostwa lub podejrzany o przestępstwa o charakterze terrorystycznym, który podjął tajną współpracę z ABW, świadomie nie ujawnił wszelkich okoliczności czynu lub działalności, o których mowa w art. 22b ust. 1.

Na podstawie art. $22 \mathrm{~b}$ ust. $8 \mathrm{w}$ przypadku zagrożenia życia lub zdrowia osoby, o której mowa w ust. 1 art. 22b, lub osób przez nią wskazanych Szef ABW stosuje wobec tej osoby lub osób przez nią wskazanych odpowiednie do zagrożenia środki ochronne, a także zapewnia niezbędne środki pomocy, w tym szczególnie uzasadnionych przypadkach, także pomoc finansową.

Przepisy art. 35 ust. 3 i art. 36 stosuje się odpowiednio. Należy zauważyć, iż na podstawie art. 35 ust. 3 osoby udzielające ABW pomocy przy wykonywaniu czynności operacyjno-rozpoznawczych mogą posługiwać się dokumentami, które uniemożliwiają ustalenie danych identyfikujących funkcjonariusza oraz środków, którymi posługuje się przy wykonywaniu zadań służbowych.

Dokumenty legalizacyjne ${ }^{52}$ są to dokumenty zawierające nieprawdziwe dane o osobach, na które te dokumenty zostały wystawione, czyli dokumenty nadające osobom fizycznym fałszywą tożsamość. Mogą one dotyczyć nie tylko osób fizycznych, lecz także wszelkich innych podmiotów prawa, np. podmiotów gospodarczych lub osób prawnych.

Pierwszym aktem prawnym penalizującym zachowania polegające na podrabianiu albo przerabianiu dokumentów, ich uzyskiwaniu, udzielaniu lub dostarczaniu, lecz jednocześnie zawierającym klauzulę wyłączającą bezprawność tych zachowań w określonych sytuacjach było rozporządzenie Prezydenta Rzeczypo-

52 R. Lizak, Dokumenty legalizacyjne w stużbach specjalnych, Prok. i Pr. 2013, nr 2, s. 142 n. 
spolitej z dnia 24 października 1934 r. o niektórych przestępstwach przeciwko bezpieczeństwu państwa. Przepisy art. 2 w zw. z art. 19 i 20 rozporządzenia uprawniały do podrabiania albo przerabiania dokumentów, ich uzyskiwania, udzielania lub dostarczania, po uprzednim uzyskaniu zezwolenia właściwego organu państwowego.

Ustawa z dnia 21 lipca 1995 r. o zmianie ustawy o urzędzie Ministra Spraw Wewnętrznych, o Policji, o Urzędzie Ochrony Państwa, o Straży Granicznej oraz niektórych innych ustaw ${ }^{53}$ wprowadziła podstawę ustawową pozwalającą na posługiwanie się dokumentami legalizacyjnymi przez funkcjonariuszy Policji, UOP.

Użycie dokumentów legalizacyjnych ${ }^{54}$ może nastąpić w celu uniemożliwienia ustalenia wszystkich cech identyfikacyjnych, które składają się na tożsamość formalną (na tożsamość formalną składają się cechy identyfikacyjne osoby możliwe do wyartykułowania, np. dane personalne). Przepisy ustaw o ABW oraz AW i SKW, a także SWW stanowią, że ABW i SWW sporządzają i wydają dokumenty legalizacyjne.

Zdaniem K. Karsznickiego ${ }^{55}$ np. przepisy ustawy o CBA nie stanowią podstawy prawnej do wytwarzania wszelkich dokumentów związanych z operacją specjalną, np. aktów notarialnych, decyzji organów administracyjnych itp. Zdaniem tego autora chodzi tylko o takie dokumenty, których zadaniem będzie ukrycie prawdziwej tożsamości funkcjonariuszy biorących udział w operacji, a także uniemożliwienie identyfikacji środków, którymi ci funkcjonariusze się posługują, np. samochodów.

Natomiast zdaniem R. Lizaka ${ }^{56}$ wydanie dokumentów legalizacyjnych w ramach operacji specjalnej, np. aktów notarialnych, decyzji organów administracyjnych, nie jest niedopuszczalne, jeżeli dokumenty te uniemożliwiają ustalenie danych identyfikujących funkcjonariusza. Dlatego też — według niego — posłużenie się dokumentem legalizacyjnym w postaci aktu notarialnego zawierającego nieprawdziwe dane, w szczególności funkcjonariusza działającego pod przykryciem, nie oznacza, że doszło do przekroczenia normy ustawowej.

Należy podkreślić, że koszty zadań ABW, w których zakresie — ze względu na wyłączenie ich jawności - nie mogą być stosowane przepisy o finansach publicznych, rachunkowości i zamówieniach publicznych, są finansowane z utworzonego na ten cel funduszu operacyjnego (art. 9 ust. 3 ustawy o ABW oraz AW). Szczegółowe zasady tworzenia i gospodarowania funduszem operacyjnym określa niejawne zarządzenie Szefa ABW.

53 Dz.U. Nr 104, poz. 515.

54 R. Lizak, op. cit., s. 146.

55 K. Karsznicki, Kontrowersje wokół ustawy o Centralnym Biurze Antykorupcyjnym, Pr. i Pr. 2010, nr 3, s. 91.

56 R. Lizak, op. cit., s. 151. 
Szef ABW w przypadkach określonych w art. 22b ust. 8 stosuje środki ochronne. Środki ochronne to np. ochrona osobista i obecność funkcjonariuszy (stała lub doraźna) w pobliżu osoby chronionej, obserwacja, monitoring, sposób kontaktowania się z innymi osobami. Zagrożenie to musi być realne, a nie tylko wyimaginowane, i wynikać z różnych zewnętrznych symptomów, np. gróźb wypowiadanych pod adresem tych osób, informacji i zamachu na ich życie, szykan. Musi wystąpić przesłanka materialna — zagrożenie życia lub zdrowia osoby lub osób przez nią wskazanych. Będą to subiektywne i obiektywne odczucia osoby lub osób, zagrożenie może występować w odniesieniu do osoby lub osób. Jest to alternatywa rozłączna, co uzasadnia dopuszczalność środków ochrony tylko osobistej lub osób przez nią wskazanych, jeżeli ona sama nie zechce z niej skorzystać. Osoby wskazane nie muszą być najbliższymi w rozumieniu art. $115 \S 11$ k.k. Szef ABW zapewnia także niezbędne środki pomocy, np. pomoc w zakresie zmiany miejsca pobytu, miejsca zatrudnienia, udostępnienie lokalu służbowego, ochrona mieszkania, pomoc zakup mieszkania, świadczenia zdrowotne. W szczególnie uzasadnionych przypadkach będzie to pomoc finansowa, w zależności od możliwości finansowych ABW (fundusz operacyjny). Udzielanie środków ochronnych i środków pomocy jest obligatoryjne. Powinny być one właściwie dokumentowane (np. zobowiązanie do przestrzegania zastosowanych środków ochrony, zobowiązanie do zwrotu środków pomocy). Jako środek ochronny nie może być natomiast stosowana kontrola operacyjna, o której mowa w art. 27 ustawy o ABW oraz AW (np. podsłuch telefoniczny, pokojowy).

Zgodnie z art. 22b ust. 9 Szef ABW cofa ochronę lub pomoc w przypadku: 1) umyślnego naruszenia przez osobę objętą ochroną lub pomocą, o której mowa w ust. 8 art. 22b, zasad albo zaleceń w zakresie tej ochrony lub pomocy, 2) zaistnienia co najmniej jednej z okoliczności, o których mowa w ust. 5-7 art. 22b.

Szef ABW obligatoryjnie cofa ochronę lub pomoc w przypadkach określonych $\mathrm{w}$ art. $22 \mathrm{~b}$ ust. 9. Jeśli chodzi o umyślne naruszenie zasad albo zaleceń, ustawa nie stawia innych warunków niż umyślność działania. Pojęcie umyślności należy odnieść do regulacji art. 9 § 1 k.k. Warunek ten jest spełniony, jeżeli osoba albo złamała zalecenie lub zasadę, gdyż taki był jej zamiar (chciała to uczynić, bez względu na motyw), albo jej zachowanie zmierzało do realizacji innego celu, lecz przewidywała, że dojdzie wówczas do naruszenia, na co się godziła.

Zgodnie $\mathrm{z}$ art. $22 \mathrm{~b}$ ust. 10 - w razie cofnięcia ochrony lub pomocy w przypadkach, o których mowa w ust. 9 art. 22b, sprawca przestępstwa szpiegostwa lub podejrzany o przestępstwa o charakterze terrorystycznym jest obowiązany do zwrotu Szefowi ABW równowartości świadczeń otrzymanych w ramach pomocy, a także zwrotu dokumentów określonych $\mathrm{w}$ art. 35 ust. 3, jeżeli zostały mu wydane. Przepis stosuje się odpowiednio do osób chronionych, o których mowa w ust. 8 art. 22b. 
Zwrot świadczeń i dokumentów legalizacyjnych ma charakter obligatoryjny. Równowartość świadczeń - najczęściej, lecz nie tylko, będzie to pomoc finansowa, a świadczenie niepieniężne to zwrot w naturze (mieszkanie, samochód). Niewykonanie przez osobę zwrotu równowartości świadczeń lub dokumentów nie skutkuje możliwością wdrożenia procedury egzekucyjnej uregulowanej w ustawie z dnia 17 czerwca 1966 r. o postępowaniu egzekucyjnym w administracji (tekst jedn. Dz.U. z 2005 r. Nr 22, poz. 1954 ze zm.), jak ma to miejsce w stosunku do świadka koronnego (art. 21 ust. 4 ustawy o świadku koronnym).

Szczególnie trudna będzie realizacja obowiązków z art. $22 \mathrm{~b}$ ust. 10 wobec cudzoziemców nieprzebywających na terytorium RP.

6. Należy zauważyć, że wprowadzony nowy kontratyp pozakodeksowy tzw. szpiega i terrorysty koronnego jest interesującym rozwiązaniem, które musi być stosowane bardzo rozważnie, z zachowaniem maksymalnego profesjonalizmu i ochrony informacji niejawnych (niestety w Polsce istnieje niebezpieczeństwo ujawnienia informacji np. przy kolejnej akcji lustracyjnej), co jest niespotykane w innych demokratycznych państwach i zasługuje na krytykę. Warto zauważyć, iż w latach 1998-2016 w Polsce skazano za szpiegostwo dziewięć osób, w tym pięciu oficerów WP, czterech cudzoziemców, jedna sprawa znajduje się w sądzie, w dwóch sprawach sąd uniewinnił oskarżonych.

Jeszcze skromniej przedstawia się statystyka, gdy chodzi o przestępstwa o charakterze terrorystycznym.

W kontekście zwalczania szpiegostwa, przy okazji realizacji spraw w ostatnich latach ze strony niektórych polityków, a także tzw. anonimowych byłych funkcjonariuszy służb specjalnych, formułowano zarzut, dlaczego nie przewerbowano obcych agentów, którzy mogliby efektywnie współpracować z naszymi służbami kontrwywiadowczymi. Wykazywano przy tym rażącą nieznajomość obowiązującej w Polsce zasady legalizmu, a jej naruszenie powodowałoby odpowiedzialność karną na podstawie art. 231 k.k. Omówione przepisy art. 22b ustawy o ABW oraz AW (a także identyczne odnoszące się do SKW) dają podstawę prawną do zastosowania — przy spełnieniu wymogów ustawowych — zasady oportunizmu. Jest to więc trafne rozwiązanie, lecz bardzo trudne w stosowaniu.

Już niejako historycznie — warto przywołać wypowiedź J. Piłsudskiego ${ }^{57}$ — „Proszę panów, agentury obce to jest zjawisko stałe i codzienne, towarzyszące rok za rokiem, dzień za dniem, jest tam część naszego życia tak wielka i tak starannie w stosunku do nas ułożona, iż nasza praca — że tak powiem - jest współbieżna z pracą agentur obcych. [...] Podczas kryzysów — powtarzam — strzeżcie się agentur".

57 J. Piłsudski, Strzeżcie się agentur, „Zeszyty Historyczne” 76, Paryż 1986, s. 3-13. Tekst wypowiedzi J. Piłsudskiego na Zjeździe Legionistów 7 sierpnia 1927 r. w Kaliszu. 


\section{On spies and terrorists}

Summary

The subject of this article is the authorization of intelligence services in preventing and combating the offences of espionage and terrorism. It describes the regulations of the Second Polish Republic regarding espionage, a draft Act on Intelligence Activities, the rule of law and opportunism, and most importantly new regulations under the anti-terrorism law.

Keywords: state security, legalizing documents, terrorist offence, espionage. 